\title{
World Heritage Convention and Transnational Legal Process to Protect Indonesian Nature
}

\author{
Ary Aprianto* \\ DOI: https://doi.org/10.22304/pjih.v6n3.a4
}

Submitted: October 9, 2019 | Accepted: December 23, 2019

\begin{abstract}
The World Heritage Convention demands its states parties to strengthen mechanisms to conserve and preserve natural and cultural heritage consistently. A party to the Convention, Indonesia faces challenges to maintain the balance of economic, social, and environment considerations, pertaining to policies that affect natural heritage. Nevertheless, Indonesia remains committed to observe the Convention's rules, including ones on sustainability and conservation. As analyzed through transnational legal process theory, the performance of this commitment helps to internalize the Convention's rules into domestic context. It is suggested that Indonesia step up its interaction with the Convention's actors in the hope of expanding the internalization of the Convention since it will help Indonesia to design better nature conservation and preservation mechanism.
\end{abstract}

Keywords: Nature Conservation, Transnational Legal Process, World Heritage Convention

\section{Konvensi Warisan Dunia dan Transnational Legal Process untuk Melindungi Alam Indonesia}

\begin{abstract}
Abstrak
Konvensi Warisan Dunia menuntut negara-negara pihak konsisten memperkuat mekanisme konservasi dan pelindungan warisan alam dan budaya. Walaupun telah menjadi negara pihak, dalam membuat kebijakan yang berdampak pada warisan alam, Indonesia tetap menghadapi tantangan dalam menjaga keseimbangan antara pertimbangan ekonomi, sosial, dan lingkungan. Namun demikian, Indonesia tetap berkomitmen melaksanakan ketentuan konvensi, termasuk mengenai kelestarian dan konservasi. Setelah dianalisis menggunakan teori transnational legal process, pelaksanaan komitmen ini membantu proses internalisasi ketentuan-ketentuan konvensi ke tataran nasional. Disarankan agar Indonesia meningkatkan interaksi dengan para aktor konvensi guna mendorong proses internalisasi lebih lanjut, karena internalisasi ini membantu Indonesia membuat mekanisme konservasi dan preservasi alam yang lebih baik.
\end{abstract}

Kata kunci: Konservasi Alam, Konvensi Warisan Dunia, Transnational Legal Process

PADJADJARAN Journal of Law Volume 6 Number 3 Year 2019 [ISSN 2460-1543] [e-ISSN 2442-9325]

* Diplomat for the Ministry of Foreign Affairs of Indonesia, Jalan Taman Pejambon No. 6 Jakarta, S.H (Universitas Padjadjaran), M.P.I.L (University of Melbourne), aryaprianto@yahoo.com. 


\section{A. Introduction}

In July 2019, the Ombilin mining site in Sawahlunto, West Sumatera, was inscribed to the UNESCO World Heritage List. It was heartening to note that the inscription was followed by calls to strengthen protection to heritage sites. ${ }^{1}$ An inscription of a site to the World Heritage List is always followed by host states' responsibilities to protect and manage the site better. The Convention concerning the Protection of World Cultural and Natural Heritage has laid down mechanism to monitor states in maintaining their responsibilities, which are considered by some as intrusive to states' domestic affairs. ${ }^{2}$ Indonesia acceded to the Convention through Presidential Decree Number 26 of 1989.

Despite the mechanism, Tropical Rainforests Heritage of Sumatera (TRHS), an Indonesian site on the World Heritage List, was listed as world heritage in danger in 2011. The listing was caused by the degradation of nature in the area. Other relevant thing that should also come to mind is the occurrence of natural disasters in Indonesia. Relevant parties have pointed out that environment destruction contributes to the occurrence of natural disaster. ${ }^{3}$

Considering the problems, the study examined the relevance of the Convention to Indonesia's efforts to conserve and preserve nature. Nonetheless, it is not to exploit the gap between Indonesia's legal responsibilities under the Convention and the performance of the responsibilities. Instead, the study analyzed Indonesia's efforts to comply with the Convention's rules, from the perspective of transnational legal process theory.

Therefore, this study aims at analyzing the internalization of the Convention's rules in Indonesian domestic sphere, in line with transnational legal process. This internalization is critical since it encourages Indonesia to comply with the Convention and offers necessary method to strengthen conservation and preservation mechanisms in Indonesia. Based on the analyses, the study encourages stronger interaction with the world heritage system to further the internalization. As the rules apply only to world heritage sites, lessons-learned in observing the world heritage rules should be replicated with a view to further develop better environment management. The realization of the rules enables Indonesia to minimize the gap between national commitment and policies in the protection of nature.

1 "Pemerintah siapkan perlindungan efektif jaga warisan tambang Ombilin", https://www.antaranews.com/berita/945031/pemerintah-siapkan-perlindungan-efektif-jaga-warisantambang-ombilin, accessed on August 7, 2019; "Berstatus warisan dunia, WALHI minta stop aktivitas pertambangan", https://www.antaranews.com/berita/944845/berstatus-warisan-dunia-walhi-minta-stopaktivitas-pertambangan, accessed on August 7, 2019.

2 UNESCO (et al), Managing Cultural World Heritage, Paris: UNESCO, 2013, p. 7; UNESCO, op.cit., pp. 48 \& 53; Stefano Battini, "The Procedural Site of Legal Globalization: The Case of the World Heritage Convention", International Journal of Constitutional Law, Vol. 9, No. 2, 2011, pp. 360-361.

3 BNPB, Data Bencana Indonesia 2017, Jakarta: Pusat Data, Informasi dan Humas BNPB, 2018, pp. vii and x; United Nations, Asia Pacific Disaster Report 2019, Bangkok: UNESCAP, 2019, pp. ii, 2, 9, and 14. 
World heritage consists of natural, cultural, and mix heritage. Several studies have been dedicated to Indonesia's cultural heritage. ${ }^{4}$ Therefore, this study only discusses Indonesia's attitude pertaining to natural world heritage. Furthermore, perspectives of tourism, global recognition, or diplomacy, as will be discussed later, dominate the discussions on world heritage in Indonesia. The role of the Convention in conservation and preservation of natural heritage has received little to no attention, though certain actor has attempted to bring it to attention. ${ }^{5}$

Even though Koh introduced it to explain states' compliance to treaties, transnational legal process is preferred by the author since it refers to a process where states engage with certain treaties or international mechanism and, upon their own conviction, obey them. The study also develops a link between transnational legal process and Indonesia's national interest to prevent and reduce the risk of natural disasters. Transnational legal process has triggered criticism due to its lack of explanation behind states' motivation to observe and internalize international rules. The utilization of national interest is expected to contribute to the discussion on transnational legal process and to explain states behavior towards treaties.

The study is divided into five parts. After an introduction, an analytical framework discusses transnational legal process and national interest. The third part presents brief information on the Convention and world heritage system, as well as national interest that should be promoted. The next part is discussion on transnational legal process with respect to Indonesia's effort to fulfil its responsibilities to the Convention. The last part is the conclusion of the study.

\section{B. Analytical Framework}

Why would states consent to be bound by treaties and act in accordance with treaties' rules? Plenty of experts have offered answers to these questions based on their own legal tradition. Some invoke the relevance of treaties to states' interests or certain common goals that states want to achieve. ${ }^{6}$ As in international relations, understanding national interest is equally important in the study of international law. Since international law is also shaped by states, the role of states interest is determinative. ${ }^{7}$

4 For example, Bambang Sulistyanto, "Warisan Dunia Situs Sangiran: Persepsi Menurut Penduduk Sangiran", Wacana, Vol. 11, No. 1, 2009; Ni Luh Herawati, "Pengembangan Pariwisata Berkelanjutan Berbasis Subak Sebagai Bagian Warisan Budaya Dunia UNESCO di Desa Mengesta Kabupaten Tabanan", Jurnal Master Pariwisata, Vol. 2, No. 1, 2015.

5 CIFOR, "Laporan Tahunan 1998", https://www.cifor.org/publications/Html/AR-98/Bahasa/W-Heritage.html, accessed on October 4, 2019.

$6 \quad$ Jan Klabbers, The Concept of Treaty in International Law, The Hague: Kluwer Law International, 1996, pp. 2526; Markus P. Beham, State Interest and the Source of International Law, New York: Routledge, 2018, pp. 124125.

$7 \quad$ Markus P. Beham, ibid., pp. 123-124. 
Guzman explains that the perceived benefits of what states can expect by participating to a treaty determine their consent and compliance. Even if treaty offers global gains, states may refuse to participate if they feel they receive disadvantage. ${ }^{8}$ On the other hand, relying on states attitude toward human rights treaties, Cole sums up that compliance depends on states' rational calculation. States will comply with treaties based upon three primary reasons. First, they would behave the same way even in the absence of the treaties. Second, they are coerced into complying; and that the penalty for defection outweighs the cost of compliance. Third, they receive important benefits from compliance that outweigh its cost. ${ }^{9}$ In short, these experts argued that states' attitude with respect to treaties or other sources of international law depends on their objectives or ambitions, and whether or not the treaties can serve their attainment.

Realists of international relations argue that states interest connects very much with the accumulation of power or states survival but altruistic interests may also shape states policies. Beham describes these interests such as preventing civil unrest, inviting foreign investment or skilled foreign labor, and gaining international assistance. ${ }^{10}$

While national interest is certainly critical, Koh believes other factors must also be counted in explaining states compliance. He describes transnational legal process as "the theory and practice of how public and private actors-nation states, international organizations, multinational enterprises, non-governmental organizations, and private individuals- interact in a variety of public and private, domestic and international, fora to make, interpret, enforce, and ultimately, internalize rules of transnational law". ${ }^{11}$ He presents it as a response to scholars whom he believes rely too heavily on rationality (national interest) or identity (portrayal as law-abiding states) in explaining compliance to treaties. ${ }^{12}$

Transnational legal process is a dynamic and active process, which facilitates continuous engagement of different actors on domestic and global levels, and transforms global norms into states habitual attitude, as well as creates conviction that obedience is necessary. ${ }^{13}$ In short, Koh argues that the process of States become intimate with certain treaties, understand the relevance of the treaties to their domestic situations, and internalize the treaties rules into domestic system are more decisive than states' rational calculation only. Koh's argument represents

8 Andrew Guzman, "The Consent Problem in International Law", Berkeley Program in Law and Economics Working Paper Series, Berkeley, 2011, pp. 14-15.

9 Wade Cole, "Mind the Gap: State Capacity and the Implementation of Human Rights Treaties", International Organization, Vol. 69, No. 2, 2015, p. 407.

10 Michael G. Roskin, "National Interest: From Abstraction to Strategy", in US Army War College Guide to Strategy compiled by Joseph R. Cerami and James F. Holcomb (et.al), Carlisle, Pennsylvania: US Army War College, 2001, pp. 56-57.; Markus P. Beham, op.cit., pp. 124 and 132.

11 Harold Koh, "Transnational Legal Process", Nebraska Law Review, Vol. 75, No. 1, 1996, pp. 183-184. lbid., pp. 199-203.

13 Ibid., p. 184. Harold Koh, "Why Do Nations Obey International Law", Yale Law Journal, Vol. 106, No. 4, 1997, pp. 2645-2646. 
the logic of constructivism, which connects states compliance to their international interactions and acceptance of norms. ${ }^{14}$

Plenty of stakeholders in Indonesia have interacted, and will continue to interact, with a variety of international actors under the Convention. This interaction influents Indonesian attitude towards the Convention and helps the internalization of Convention's rules into domestic context. Transnational legal process consists of three phases: interaction, interpretation, and internalization. Interaction creates pattern of behavior and generates norms of external conduct. Interaction also results in an interpretation of certain norm that applicable in certain situation, which will be internalized by states. ${ }^{15}$ Internalization is critical since this process leads to a conviction that certain rules should, or even must, be obeyed. According to Koh, six key agents help internalization process, ${ }^{16}$ whereby four are most relevant to the topic of this paper. They are governmental norm sponsors, transnational issues network, issue linkages, and bureaucratic compliance procedure. Governmental norm sponsor is government agency whose works promote internalization. Relevant to this study, key agencies include the Forestry and Environment Ministry, Foreign Ministry, Coordinating Ministry for Human and Culture Development, Public Works Ministry, local governments, etc. Bureaucratic compliance procedure entails internal procedure of the Convention that monitors and ensures compliance of states. In the case of Indonesia's relation with the Convention, this procedure is observed through, for example, attending relevant meetings, receiving field missions, and submitting reports, which are coordinated by government agencies. Transnational issues network comprises of professionals with knowledge and competence in particular fields, such as nongovernment organizations (NGOs). Internalization is also promoted when strong linkages exist across issue areas.

However, transnational legal process is not without criticisms. Stevens believes that it lacks sufficient explanation of what motivate states to internalize certain international rules or what would make internalization a successful process. ${ }^{17}$ Invoking a moralistic principle of 'pacta sunt servanda'18 is of little relevance. After all, plenty of treaties have been concluded but contravention remains in existence. For instance, member states of the United Nations must agree that they will settle dispute in peaceful manner but armed conflicts still occur. In other words, there

14 Caleb J. Stevens, "Hunting a Dictator as a Transnational Legal Process: The Internalization Problem and the Hissene Habre Case", Pace International Law Review, Vol. 24, No. 1, 2012, p. 204. See also Filipe dos Reis and Oliver Kessler, "Constructivism and the Politics of International Law" in The Oxford Handbook of the Theory of International Law compiled by Anne Orford and Florian Hoffmann (et.al), Oxford: Oxford University Press, 2016, pp. 345-351.

15 Koh, "Why Do Nations", loc.cit.; Koh, "Transnational Legal Process", op. cit., p. 204.

16 Harold Koh, "Bringing International Law Home", Houston Law Review, Vol. 35, 1998, p. 647.

17 Caleb J. Stevens, "Hunting a Dictator as a Transnational Legal Process", op.cit., pp. 193 and 198-199.

18 See Articles 26 and 31 of the Vienna Convention on the Law of Treaties 1969. 
must be something to push states to internalization. While Stevens in his article employed Balzacq's securitization theory, this article argues that - in the case of Indonesia - it is issue linkages, in the form of understanding of 'national interest', which may help bridge this shortcoming.

This study does not discuss 'national interest' thoroughly. Instead, national interest is described simply within the perspective of domestic condition and the expected relevant goals. At the very least, it heeds Article 3 of the Law Number 37 of 1999 on Foreign Relations and Article 4 of Law Number 24 of 2000 on Treaty, which promote Indonesian national interest for foreign policy and treaty action. It is expected that the understanding of a precise national interest will further deepen the internalization of Convention's rules.

\section{The Convention}

The United Nations Educational, Scientific, and Cultural Organization (UNESCO) was established in 1945. The creation of UNESCO was the culmination of ideas to create an international organization to further education and cultural cooperation, which took shape during World War II. ${ }^{19}$ Until August 2019, UNESCO has 193 members, including Indonesia. ${ }^{20}$

Convention concerning the Protection of World Cultural and Natural Heritage (the Convention) was adopted under the auspices of UNESCO in 1972. The principal organs of the Convention are the General Assembly of State Parties, the World Heritage Committee, and the Secretariat. The Committee consists of 21 state parties that are elected by the Assembly. The World Heritage Centre assumes the functions of the Secretariat. The Centre is responsible, inter alia, to organize meetings of the Assembly and the Committee; receive, check, and transmit nomination documents to relevant bodies; and prepare and organize monitoring of sites. $^{21}$ The Committee has several important tasks, including deliberating and deciding on the nominations to the World Heritage List, listing and delisting of a site to the list of World Heritage in Danger, and removing a site from the World Heritage List. $^{22}$

Three independent Advisory Bodies assist the implementation of the Convention. They are the International Union for the Conservation of Nature and Natural Resources (IUCN), International Centre for the Study of the Preservation and Restoration of Cultural Property (ICCROM), and International Council on Monuments and Sites (ICOMOS). IUCN is responsible for natural heritage; while ICOMOS and ICCROM have duties with respect to cultural heritage. The critical duties of these bodies are, among others, to evaluate and assess sites that are

\footnotetext{
19 H.H. Krill de Capello, "The Creation of United Nations Scientific, Educational, and Cultural Organization", Journal International Organization, Vol. 24, No. 1, 1970, pp. 4-5.

20 UNESCO, "Member States Information", http://www.unesco.org/new/en/member-states/member-statesinformation/, accessed on August 28, 2019.

21 The World Heritage Convention Article 14, the Operational Guidelines Paragraphs 27-28.

22 The World Heritage Convention Article 11, the Operational Guidelines Paragraphs 153-160, 175-198.
} 
nominated to the World Heritage List, to monitor the state of conservation of world heritage sites and report the result to the Committee, and to carry out field mission to monitor world heritage sites. ${ }^{23}$

Currently, the World Heritage List contains 1.121 sites that are located in 167 state parties. ${ }^{24}$ Nomination to the World Heritage List requires a site to be of outstanding universal values (OUVs) and meet at least one out of ten criteria of OUVs. The criteria are explained in Articles 1 (for cultural heritage) and 2 (for natural heritage) of the Convention, and are elaborated further in Paragraph 77 of the Operational Guidelines of the Convention.

The advisory bodies examine nomination documents. It includes assessment on OUVs as suggested by states and relevant protection and management mechanism. ${ }^{25}$ Based on their examination, advisory bodies may or may not recommend inscription to World Heritage List. ${ }^{26}$ The Committee and the advisory bodies also monitor state's conservation of a site. If they receive report of threats to a site, the Committee will ask host state to provide clarification. ${ }^{27}$ If the advisory bodies determine there are serious threats to OUVs, authenticity, and/or integrity of a site, the Committee can suggest state party to receive the visit of Reactive Monitoring Mission. ${ }^{28}$

\section{Indonesia's Interests towards The Convention}

The Presidential Decree Number 26 of 1989 does not offer explanation behind Indonesia's accession to the Convention. It only mentions that the world cultural and natural heritage must be preserved. Yet in the 1970s, UNESCO provided technical assistance and funding for Indonesia in restoring Borobudur temple. ${ }^{29}$ Accordingly, the possibility of getting international assistance in preserving national heritage could be the motivation of Indonesia to join the Convention, and to comply with it.

In the years after, other purposes came to motivate Indonesia towards the Convention. The listing of Indonesian cultural and natural heritage is seen as a global recognition to Indonesian culture and commitment to preserve nature, as well as a source of pride. ${ }^{30}$ The listing enables world heritage sites to be a popular tourist attraction as suggested by Indonesian Minister for Tourism. ${ }^{31}$

23 The World Heritage Convention Article 8 (3), the Operational Guidelines Paragraphs 30-37.

24 UNESCO, "The World Heritage Convention", "The List", http://whc.unesco.org/en/list/, accessed on August 29, 2019.

25 The Operational Guidelines, Paragraphs 143-151. UNESCO (et. al), Preparing World Heritage Nominations, Paris: UNESCO, 2011, pp. 125-129.

26 The Operational Guidelines, Paragraph 151.

27 UNESCO, Managing Natural World Heritage, op.cit., p. 24.

28 Operational Guidelines Paragraphs 169-176.

29 See I.G.N. Anom, The Restoration of Borobudur, Paris: UNESCO, 2005.

30 "Kunjungi Taman Nasional Komodo, Jokowi: Jaga dan https://www.beritasatu.com/nasional/335865/kunjungi-taman-nasional-komodo-jokowi-jaga-dan-rawat, 
Therefore, it is not surprising if tourism purpose and national image are seen as the interests behind Indonesian participation to the world heritage system. Developing national image is one of the government's priorities, according to President Joko Widodo. A stronger national brand would make Indonesia be in a better position to compete with other countries, especially in trade, investment, and tourism. ${ }^{32}$ Tourism has long been high on the government's agenda for its contribution to national development. World heritage sites in Indonesia are to be developed into tourism site to attract foreign and domestic visitors alike. Komodo National Park offers a good example for this purpose.

The motivations are also in line with several advantages that have been identified by UNESCO to encourage states participation to the Convention. Inscription to the World Heritage List serves as a catalyst to raise domestic awareness for heritage protection. It also brings prestige to the host countries and supports tourism and economic development. ${ }^{33}$ The most important advantage is that the sites enjoy an elaborate protection and monitoring mechanism. ${ }^{34}$

Indonesia has nine world heritages. Five of them are cultural sites: Borobudur Temple Compounds, Prambanan Temple Compounds, Subak - the Cultural Landscape of Bali Province, Ombilin Coal Mining Heritage, and Sangiran Early Man Site. The other are four natural sites: Komodo National Park, Lorentz National Park, Ujung Kulon National Park, and Tropical Rainforests Heritage of Sumatera (TRHS).

TRHS was put on the list of world heritage in danger in 2011. The Convention defines world heritage in danger as a world heritage that is threatened by serious and specific danger, such as disappearance, destruction, major alterations, abandonment, armed conflict, natural calamities, human encroachment, or modification to legal status of the site. Serious threats to TRHS include roads development plan, human encroachment, poaching and illegal wildlife trade, and mining and geothermal energy development. IUCN mission in 2018 revealed that due to encroachment, TRHS had lost $15 \%$ of its land, amounting to approximately 390,000 hectares. IUCN warned that the encroachment also took place in areas with significant ecological benefits. With respect to actors behind the

accessed on August 9, 2019; “Gubernur Sumbar: Perlu Komitmen Menjaga Kawasan Warisan Alam Untuk Jaga Kepercayaan UNESCO”, https://www.semangatnews.com/gubernur-sumbar-perlu-komitmen-menjagakawasan-warisan-alam-untuk-jaga-kepercayaan-unesco/?page28332434234=5, accessed on August 21, 2019.

31 "Menpar: Status internasional Ombilin Sawahlunto bakal tarik wisatawan", https://katadata.co.id/berita/2019/07/09/menpar-status-internasional-ombilin-sawahlunto-bakal-tarikwisatawan, accessed on August 7, 2019.

32 "Citra Positif Bukan Hanya Logo dan Slogan", http://ksp.go.id/presiden-jokowi-citra-positif-bukan-hanyasekedar-logo-dan-slogan/index.html, accessed on August 112019.

33 Lynn Meskell, “UNESCO's World Heritage Convention at 40: Challenging the economic and political order of international heritage conservation", Current Anthropology, Vol. 54, No. 2, 2013, p. 483; See also JoAnn Vrabel, "Tourism at UNESCO World Heritage Sites: Protecting Global Treasures and the Travelers Who Seek Them", Case Western Reserve Journal of International Law, Vol. 46, No. 3, 2014; Christoph Brumann, "Shifting tides of world making in the UNESCO World Heritage Convention: cosmopolitanism colliding", Ethnic and Racial Studies, Vol. 37, No. 12, 2014.

34 See UNESCO, Managing Natural World Heritage, op.cit., pp. 20-34. 
encroachment, IUCN stressed that commercial actors, as well as small scale farmers, were responsible. ${ }^{35}$

TRHS comprises of three national parks: Gunung Leuser (in the Provinces of Aceh and North Sumatera), Kerinci Seblat (in the Provinces of West Sumatera, South Sumatera, Jambi, and Bengkulu), and Bukit Barisan Selatan (in the Provinces of Lampung and Bengkulu). To remove it from the list of world heritage in danger, Indonesia has been rehabilitating degraded land in TRHS, developing better and more sustainable model of management, and preventing its further degradation. Progresses of these efforts are reported annually to the Committee.

Meanwhile, Lorentz National Park is the largest protected area in Southeast Asia, with more than 2.3 million hectares of land at the time of inscription in 1999 . IUCN in 2017 classified Lorentz National Park as meriting 'significant concern'. This classification is given to world heritage sites whose values are threatened and/or are showing signs of deterioration. Significant additional conservation measures are needed to maintain and/or restore values over the medium to long term. ${ }^{36}$

There are at least two most critical threats to Lorentz National Park, based on IUCN evaluation: (1) roads construction inside the park, including the Trans-Papua highway; (2) the die-back of Nothofagus forest. This mysterious disease has infected Nothofagus forests along the road's construction, and has been identified since 2004. ${ }^{37}$ To monitor these threats, the Committee has dispatched three field missions to the park.

\section{Transnational Legal Process and The Internalization of The Convention}

As prescribed earlier, Koh argued that participation of states in a variety of international processes help the internalization of international rules into domestic context. Internalization may take three forms: social, legal, and political. Social internalization occurs when a norm acquires public legitimacy. Political internalization occurs when political elite accepts a norm and advocates it as part of government policy, while legal internalization occurs when a norm is incorporated into domestic legal system through executive action, legislative action, judicial interpretation, or others. The precise sequencing among political, social, or legal internalization may vary from case to case. ${ }^{38}$

Interaction between domestic and international actors creates pattern of behavior - what is expected and what is not expected. Further process involves interpretation, in which interaction sheds light into confusion or different

\footnotetext{
35 IUCN, Mission Report - Tropical Rainforest Heritage of Sumatera, 5-16 April 2018, World Heritage Committee Document 42 COM, 2018, pp. 5-6.

36 Elena Osipova (et al), IUCN World Heritage Outlook 2: A conservation assessment of all natural World Heritage sites, Gland, Switzerland: IUCN, 2017, pp. 11 and 28.

37 IUCN, Mission Report - Lorentz National Park, 11-18 March 2014, World Heritage Committee Document 38 COM, 2014, pp. 8-9.

38 Koh, "Bringing International Law", op.cit., p. 642.
} 
perspectives on how international rules should be understood and observed. ${ }^{39}$ The rules will be internalized through incorporation into domestic legal and political system. This internalization is not done through coercion but is based on states' conviction that the rules are part of their internal value. ${ }^{40}$ The end process is an obedience, which Koh described as an 'internalized compliance' ${ }^{41}$

In the case of Indonesia, its accession to the Convention can be considered as a sort of legal internalization through executive action (presidential decree). Law Number 26 of 2007 on Spatial Planning designates a world heritage site as a National Strategic Zone, which also represents a sort of legal internalization of the Convention. Yet no further reference on world heritage can be found on other relevant laws. Laws Number 41 of 1999 and 19 of 2004 on Forestry, as well as Law Number 18 of 2013 on Prevention of Forest Degradation, make no mention on world heritage. Law Number 5 of 1990 on Conservation of Biodiversity and Ecosystem provides basic rules on national park - what can and cannot be done in national parks. Since natural world heritage in Indonesia are all national parks, Law Number 5 of 1990 and its implementing regulations are critical to support legal internalization of the Convention (though the Law makes no mention of world heritage either). At the very least, states must apply international rules in their domestic legal system to make the rules operative in the domestic context. As a general practice, this application can take several forms, including through legislative actions. ${ }^{42}$

In his defense of his theory, Koh argues that the application of transnational legal process goes beyond treaty-compliance by states. Among the examples he discusses are the International Court of Justice dispute between United States and Nicaragua, the process leading up to the adoption of anti-personnel landmine treaty, ${ }^{43}$ or the earlier efforts to prevent North Korea from developing nuclear weapons ${ }^{44}$. Transnational legal process will be discussed below with the help of three important characteristics of the Convention: understanding of the value of world heritage, sustainability, and engagement of multi actors.

\section{Instilling the Value of World Heritage}

Among the successes of the Convention is that it has instilled, among countries, the commitment to preserve and transmit cultural and natural heritage of 'outstanding universal values' to future generations, and encouraged the incorporation of this commitment into domestic laws and policies. ${ }^{45}$ The key elements of the Convention

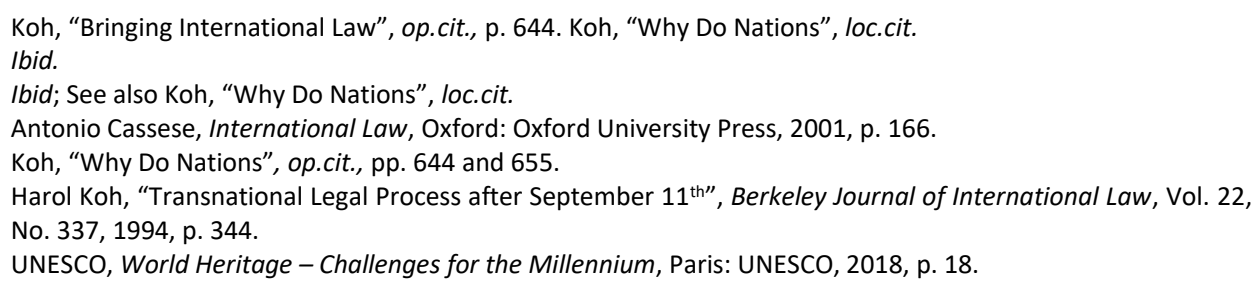


lie on Articles 4, 5, and $6 .{ }^{46}$ Article 4 underlines that the duty to identify, protect, conserve, present, and transmit to future generation cultural and natural heritage in state's territory primarily belong to the state concern. Article 5 enumerates certain policies and actions that must be undertaken by state. Complementing Article 4, Article 6 (1) stresses that the duty to protect such heritage falls to the international community as a whole through cooperation. Article 6 (3) further reminds state not to take any deliberate measures that might damage world heritage in its territory.

Those three articles constitute the foundation of interaction between national actors and international system. Through the articles, national actors learn the underlying message that a world heritage is an asset not only of each individual nation but also of humanity as a whole, which then justifies international monitoring and cooperation for its protection. ${ }^{47}$ While states retain their sovereignty, states freedom is no longer absolute in a sense that they cannot do anything that might damage the heritage.

An inter-ministry coordination mechanism has been set up at the central government level of Indonesia to further develop common understanding on the importance of protecting world heritage and discuss ways to overcome challenges. ${ }^{48}$ Alignment with provincial actors is also conducted to ensure synergy between local and national policies. In August 2019, for example, the Provincial Government of West Sumatera expressed its commitment to work together to rehabilitate TRHS areas in West Sumatera. ${ }^{49}$ Prior to that, Aceh provincial officials also expressed their commitment to restore TRHS areas in Aceh, including cancelling geothermal project that was considered as having negative effects. Taking advantage of the visit of IUCN monitoring team, Aceh officials also stated their readiness to work together in exploring model of development that promote sustainability. ${ }^{50}$

While motivation to rehabilitate TRHS may different from one actor to the others (to maintain Indonesia's international profile, protecting nature, or recognizing TRHS as a source of local and national pride), all actors at least recognized that they have international responsibility in protecting TRHS. They also realized that the international community, through UNESCO, monitored the

\footnotetext{
46 Stefano Battini, "The Procedural Site of Legal Globalization”, op.cit., page 351; UNESCO (et. al), Preparing World Heritage Nominations, op. cit., p. 14.

47 UNESCO (et. al), ibid.

48 "Kemenko PMK Minta Masyarakat Sadar Pentingnya Warisan Dunia, Ini Penjelasannya", https://www.beritarayaonline.co.id/kemenko-pmk-minta-masyarakat-sadar-pentingnya-warisan-dunia-inipenjelasannya/, accessed on October 1, 2019.

49 "Sumbar Komitmen Keluarkan Taman Kerinci Dari Status Bahaya", https://www.gatra.com/detail/news/439350/lifestyle/sumbar-komitmen-keluarkan-taman-kerinci-daristatus-bahaya, accessed on September 22, 2019.

50 "Wagub: Geothermal di Gayo Lues Dibatalkan", http://cakradunia.co/news/wagub-geothermal-di-gayo-luesdibatalkan/index.html, accessed on September 22, 2019.
} 
execution of their responsibility. As was stressed by an official from the Coordinating Ministry of Human and Culture Development, "Indonesia nominated TRHS as world heritage so it is our responsibility to take care of it". ${ }^{51}$ All of these commitments represent a sort of political internalization, in which Indonesian government agencies, fully aware of Indonesia's international responsibility, advocates the rehabilitation of TRHS, creation of a better management system at TRHS, and realization of a more sustainable model of development.

Interaction and interpretation also take place when Indonesia develops and executes its protection and management plan. Management plan usually includes baseline data, risks assessment, goals, and relevant activities. ${ }^{52}$ There are no guidance as to what constitute 'effective legal protection' or 'a good management plan'. However, IUCN asserts that both must enable the attainment of the Convention's goals. ${ }^{53}$

An example from a mission to Lorentz National Park in 2014, IUCN opined that the Office of Lorentz National Park (Balai Taman Nasional) did not have sufficient capacity to oversee the management and protection of the park. While efforts to increase the Office's budget, equipment, and human resources were commended, IUCN concluded that the vast area of Lorentz National Park remained above the office's capacity. Interestingly, IUCN also suspected that the head of Lorentz office did not have enough leverage when coordinating with heads of other institutions because Lorentz office occupied a low level in the government hierarchy (echelon IIIb). ${ }^{54}$

That field mission reflects further interaction among actors, in which IUCN (as actor to the Convention) provides relevant interpretation of Convention's rules. While some may consider it went too far with respect to Indonesia's domestic policies, IUCN report was made in line with its responsibility to monitor state of conservation of a site, including strength and weaknesses of the state's protection and management system. Hence a reiteration of what is expected and not expected from Indonesia as party to the Convention.

Meanwhile, while it understood the economic and social needs of roads development for communities in Lorentz, IUCN criticized Indonesia for not completing environment impact assessment prior to the development and the lack of mitigation for possible environment impact. ${ }^{55}$ Paragraph 96 of the Operational Guidelines states that OUVs, as well as authenticity and integrity of the site, at the time of its inscription must be sustained or enhanced with the passing of time. This means that any alteration or modification of the site, which will decrease or negate

\footnotetext{
51 "Situs Warisan Dunia Diupayakan Keluar Dari Status Bahaya, Begini Komitmen Pemerintah", https://www.mongabay.co.id/2017/08/03/situs-warisan-dunia-diupayakan-keluar-dari-status-bahaya-beginikomitmen-pemerintah/, accessed on September 22, 2019.

52 UNESCO, Managing Natural World Heritage, op.cit., pp. $37-42$.

53 Ibid., pp. $35-36$.

54 IUCN, Mission Report - Lorentz National Park, 11-18 March 2014, p. 12.

55 Ibid., pp. 13-15.
} 
OUVs as well as authenticity and integrity of the site, will not be tolerated. State must notify the Secretariat if they plan major restoration or construction in the site. In so doing, the Secretariat will be able to assist States in determining possible ways to preserve OUVs. ${ }^{56}$ This mechanism, while limiting the freedom of states, is necessary to ensure that further development of the site does not lead to its deterioration.

\section{Intensifying Sustainability}

While the Convention does not contain the term 'sustainable development', UNESCO argues that the spirit of sustainability can be deduced from Articles 4 and $5 .^{57}$ The notion of sustainable development is integrated into the world heritage system following the adoption of Budapest Declaration in 2002 and the Policy Document for the Integration of Sustainable Development Perspective into the Processes of the World Heritage Convention in 2015. Both documents underline the importance of striking a balance between conservation, sustainability, and development; so that world heritage will be beneficial to social and economic life.

The 2030 Agenda for Sustainable Development, concluded in 2015, contains several Goals that are relevant to nature, such as Goals 13, 14, and 15 that deal with climate, life below water, and life on land. The role of nature is also critical in the attainment of other Goals, such as Goals 2 (food) and 3 (health). IUCN has pointed out that natural world heritage, through its OUVs, offers biodiversity and ecosystem services to humanity, ranging from providing energy, clean water, and fresh air to trap energy from the sun and the building of soil. ${ }^{58}$

Interaction with world heritage actors then provides an opportunity for Indonesia to further the spirit of sustainability in domestic context. On TRHS, IUCN has for years been suggesting Indonesia to adopt more sustainable form of development. In its mission in 2007, several key points were made by IUCN, for example on illegal logging, forest encroachment because of palm oil expansion and community agriculture, and management system that does not reflect the spirit of sustainability. ${ }^{59}$ This suggestion resonates very much with the condition of nature in Indonesia. To take an example, the Forestry Ministry in 2018 reported that in the period of 1996-2000, 3.51 million hectares of forest lost annually. In the

\footnotetext{
Paragraph 172 of the Operational Guidelines.

UNESCO, "Sustainable "World Heritage Convention", https://whc.unesco.org/en/sustainabledevelopment/, accessed on September 10, 2019.

58 Elena Osipova (et.al.), The Benefit of Natural World Heritage: Identifying and Assessing Ecosystem Services and Benefits Provided by The World's Most Iconic Natural Places, Gland, Switzerland: IUCN, 2014, p. 2.

59 IUCN, Mission Report - Tropical Rainforest Heritage of Sumatera, 5-11 March 2007, World Heritage Committee document 31 COM, 2007, pp. 4-9.
} 
subsequent years, Indonesia was able to reduce deforestation though the rate remains high. ${ }^{60}$

The impacts of deforestation have been described in plenty of papers. Researchers suggest that deforestation reduces rainfall. Trees absorb water from land and rainfall, and release water vapor into the atmosphere. Water vapor accumulates, turn into clouds, and then create rainfall. Research also suggests that air that passes over extensive vegetation produces twice as much rain as air that passes over land with less vegetation. ${ }^{61}$ Deforestation also releases carbon dioxide that makes the earth dryer and warmer.

In a way, the Committee's decision to enlist TRHS into the World Heritage in Danger 'forced' Indonesia to adapt a more sustainable model of forest management. Indonesia is required to devise a plan for rehabilitation of TRHS and to effectively execute the plan so as to restore its condition. IUCN will assess the progress of rehabilitation, based on annual report submitted by Indonesia, and offer input. This interaction allows not only interpretation of relevant rules of the Convention but also facilitate the application of international standards within domestic context. In 2018 for example, Indonesia developed a roadmap to increase the population of endangered species in TRHS, such as elephants, tiger, and orangutans. Other than to fulfill Indonesia's responsibility to the Convention, the roadmap was also developed as a recognition to the species' role in ecology and science. ${ }^{62}$

In 2013, Indonesia agreed to conduct a Strategic Environment Assessment (SEA) on the roads development in TRHS. ${ }^{63}$ SEA then concluded that the roads development will likely have negative impacts to OUVs, including habitat loss and biodiversity conflicts, and creating physical barrier to natural interaction between sub-population of species in isolated areas. Indonesia was recommended not to continue with roads development and to prioritize maintenance of existing roads. ${ }^{64}$ The result of SEA was presented to government actors, which allowed the government to engage in further discussions (interpretation process). Indonesia's policy to stop roads development represent internalization of the principle of sustainability. This policy is significant considering criticisms that have been raised particularly against SEA in Indonesia. While it is regulated on Law Number 32 of 2009 on Protection and Management of Nature Environment, actors criticized SEA

60 Kementerian Lingkungan Hidup dan Kehutanan, Status Hutan dan Kehutanan Indonesia 2018, Jakarta: Kementerian Lingkungan Hidup dan Kehutanan, 2018, p. 29.

61 Fred Pearce, "Rivers in the sky: how deforestation is affecting global water cycles", https://e360.yale.edu/features/how-deforestation-affecting-global-water-cycles-climate-change, accessed on September 18, 2918; David Ellison (et.al), "Trees, Forests, and Water: Cool Insights for a Hot World", Global Environmental Change, Vol. 43, 2017, pp. 53-54.

62 Indonesia, State of Conservation Tropical Rainforests Heritage of Sumatera 2019, pp. 8-9.

63 World Heritage Committee Decision Number 37 COM 7A 14, 2014.

64 World Heritage Committee Decision Number 41 COM 7A.18, 2017. 
upon reason that it is conducted merely for administrative requirement or that development often ignores SEA. ${ }^{65}$

Indonesia's policies above are also consistent with research conducted by Conradin and Wiesmann, which concluded that world heritage status does encourage states to step up their protection and management mechanism. International recognition of the site, potential damage to states reputation if the sites are damaged, and international support serve as motivation for states to enhance their protection mechanisms. ${ }^{66}$

\section{Agents for Internalization}

There are links between Koh's idea on agents for internalization and the Convention, in the form of NGOs and issue linkages. The Convention recognizes the right of party other than State to submit concern to the Secretariat with respect to condition of a site. ${ }^{67}$ Based upon the information received, the Secretariat will invite State to give clarification. Example of this mechanism, among others, is the development of hotel and mining activities in the Aeolian Islands, a natural world heritage in Italy, whereby the Secretariat also received report from several NGOs. ${ }^{68}$

Receiving information from and reaching out to non-state actors, notably NGOs, enable advisory bodies to gather as many as possible relevant input on the state of conservation of a site. It also ensures that concern of local community, which sometimes is sidelined by government interests, can be accommodated in the evaluation of the site. NGOs have been recognized as facilitating the link between society, their identity, and conservation purpose; as well as advocating for environment cause. ${ }^{69}$ Further, constructivist theory of international law recognizes NGOs for its role in facilitating dialogue and helping internalize international norms into national framework. ${ }^{70}$

In Indonesia, other than with government officials, IUCN met and had dialogue with non-state actors when they monitored a site. The Desired State of Conservation to remove TRHS from the list of World Heritage in Danger was

65 Walhi, Siaran Pers tanggal 24 Oktober 2019, “https://walhi.or.id/dalam-pusaran-oligarki-masa-depan-surammembayangi-pemerintahan-indonesia-majuDalam Pusaran Oligarki, Masa Depan Suram Membayangi Pemerintahan Indonesia Maju", accessed on December 2, 2019.

66 Katharina Conradin and Urs Wiesmann, "Does World Natural Heritage Status Trigger Sustainable Regional Development Efforts?" Journal on Protected Mountain Areas Research and Management, Vol. 6, No. 2, 2014, p. 7; Katharina Conradin and Thomas Hammer, "Making the Most of World Natural Heritage - Linking Conservation and Sustainable Regional Development?", Sustainability, Vol. 8, No. 4, 2016, pp. 5-7.

67 Paragraph 174 of the Operational Guidelines.

68 IUCN, Mission Report - Aeolian Islands, 21-28 March 2007, World Heritage Committee document 31 COM, 2007, pp. 2 and 8.

69 Alessandro Chechi, "Non-state Actors and the Implementation of the World Heritage Convention in Asia: achievements, problems, and prospects", Asian Journal of International Law, Vol. 8, No. 2, 2018, p. 471.

70 Filipe dos Reis and Oliver Kessler, op.cit., pp. 349-350. 
developed with the assistance from various national NGOs. ${ }^{71}$ In IUCN mission to TRHS, in 2018, local NGOs assisted IUCN team by also providing logistical and financial contributions, as well as thoughts and information. ${ }^{72}$ Back in 2011, IUCN received information on illegal poaching of tortoise in Lorentz National Park, reported on local newspaper in Papua. Based on this information, IUCN conducted relevant survey during their subsequent visit to Lorentz National Park. ${ }^{73}$ An NGO (in this case, WWF Indonesia) worked with Lorentz National Park to finalize an agreement for the involvement of local communities in the park management. ${ }^{74}$

Meanwhile, sustainable development serves as an important issue linkage in encouraging further internalization of the convention. Adding to the discussion in the previous part, Indonesia has been pursuing the incorporation of sustainable development goals (SDGs) into national development agenda. Presidential decree Number 59 of 2017 stressed on the need to harmonize SDGs into national development plan and mapped out national goals that contribute to SDGs. Several of these national goals correspond with what IUCN has been advising Indonesia pertaining to management of TRHS and Lorentz, such as increasing forest cover, rehabilitation of degraded lands, and better law enforcement for crimes against nature. A road map on SDGs Indonesia, which is under process ${ }^{75}$, can make sustainable development becomes more high profile as an issue linkage. The spirit of SDGs has also been invoked by national actors with respect to protection of nature and natural world heritage, notably the link between ecosystem service, ecosystem deterioration, and life. ${ }^{76}$

Other issue linkage that comes to mind is on preventing and reducing the risk of natural disasters. Indonesia is frequented by natural disasters, notably those that are caused by climate change and nature deterioration. ${ }^{77}$ Indonesia's National Agency for Disaster Management (BNPB) reported, there were 2.868 and 3.405 natural disasters in 2017 and 2018 respectively. ${ }^{78}$ In 2018, the Agency recorded 871 incidents of flood, 614 incidents of land flow, as well as 527 incidents of land and forest fire. More than six thousand people lost their lives, while more than 10 million others were affected or misallocated.

Sustainability and conservation of nature have been recognized as essential elements to reduce the adverse impact of climate change and tackle disaster risk

71 IUCN, Report on the Mission to Jakarta, from 24 to 30 October 2013, Regarding the Tropical Rainforest Heritage of Sumatera, Gland, Switzerland: IUCN, 2013, pp. 12-13.

72 IUCN, Mission Report - Tropical Rainforest Heritage of Sumatera, 5-16 April 2018, op.cit., pp. 4 and 5.

73 IUCN, Mission Report - Lorentz National Park, 24 January - 3 February 2011, World Heritage Committee Document 35 COM, 2011, p. 14.

74 IUCN, Mission Report - Lorentz National Park, op.cit., pp. 12-13.

75 “Peta Jalan SDGs Ditargetkan Selesai Tahun Ini”, https://ekonomi.bisnis.com/read/20190121/9/880734/petajalan-sdgs-ditargetkan-selesai-tahun-ini, accessed on October 3, 2019.

76 Kementerian Lingkungan Hidup dan Kehutanan, Status Hutan, op.cit., pp. 12, 14, and 18.

77 "80 persen bencana di Indonesia akibat perubahan iklim", https://ugm.ac.id/id/berita/8496-80-persenbencana-di-indonesia-akibat-perubahan-iklim, accessed on August 15, 2019; See also, BNPB, Data Bencana Indonesia 2017, loc.cit.

78 See Data Informasi Bencana Indonesia, http://bnpb.cloud/dibi/tabel1a, accessed on August 15, 2019. 
drivers, most notably by the Paris Agreement and Sendai Framework for Disaster Risk Reduction. The importance of protecting nature and advancing sustainability have also been asserted in various Indonesia's development documents, such as Long-term Development Planning (Law Number 17 of 2007) and the National Plan of Action on Climate Change Adaptation.

Therefore, sustainable development as well as preventing and reducing the risk of natural disaster serve more than just to intensify internalization but should also be promoted as Indonesia's interests to deal with the Convention. These two issue linkages will also address Stevens' concern on why states are willing to internalize international rules. By taking example, BNPB stated the economic cost of forest and land fire in 2015 amounted to Rp221 trillion. ${ }^{79}$ This financial loss is tremendous. Think about the progress of Indonesia's national development if natural disasters are prevented and reduced, so that the fund is channeled to other important sectors. As comparison, national budget for research and development only amounted to Rp24.9 trillion in $2019^{80}$, while the deficit experienced by BPJS (Indonesia's national health security institution) in 2019 was predicted at between Rp28 - 32 trillion. ${ }^{81}$

\section{E. Conclusion: Towards Further Internalization of The Convention in Indonesia}

Similar to other states, the realizations of sustainable development that balances economic, social, and environment interests, as well as between the needs of the present and the future, is a huge challenge for Indonesia. There have been criticisms related to the realization of the government's commitment to protect the environment. ${ }^{82}$ The Convention offers good mechanism to help address such challenges. This study has shown how transnational legal process explains Indonesia's attitude towards the Convention's rules. It also explains that the understanding of a precise national interest - sustainability and preventing natural disasters - may help transnational legal process in advancing internalization. Interaction and engagement with world heritage actors have given Indonesia opportunities to reconsider its policies and their impacts to nature and sustainability. Evaluation and comments from global actors give further impetus to this process, allowing (or forcing) Indonesia to generate policies that serves nature

\footnotetext{
79 "BNPB catat kerugian akibat kebakaran hutan 2015 Rp221 triliun”, https://nasional.republika.co.id/berita/nasional/umum/15/12/20/nzms82359-bnpb-catat-kerugian-akibatkebakaran-hutan-2015-rp-221-triliun, accessed on October 2, 2015.

80 "Presiden Jokowi Soroti Anggaran Riset Rp24,9 Triliun: Itu Gede Banget", https://nasional.republika.co.id/berita/nasional/umum/15/12/20/nzms82359-bnpb-catat-kerugian-akibatkebakaran-hutan-2015-rp-221-triliun, accessed on October 2, 2018.

81 "BPJS kesehatan bisa deficit Rp32,8T jika iuran tak naik", https://www.cnnindonesia.com/ekonomi/20190827205233-78-425181/bpjs-kesehatan-bisa-defisit-rp328-tjika-iuran-tak-naik, accessed on September 27, 2019.

82 See, for example, Walhi, Tinjauan Lingkungan Hidup 2019, Jakarta: Wahana Lingkungan Hidup Indonesia, 2019, pp. 72-76.
} 
interests. Requirements to submit reports and field visit has furthered the internalization of Convention's rules into domestic context. There remains a big question on whether Indonesia would be willing to observe such complex rules on conservation and preservation had it not been party to the Convention.

Based on the discussions, further interaction between Indonesia and the world heritage system will help the deepening of the convention's rules and the spirit of sustainability. The growing participation of NGOs, communities, or academic institutions, as key agents of internalization, will also contribute in this internalization process. The fact that nature deterioration remains prevalent suggests that more efforts must be done to deepen internalization. Some possible efforts include strengthening the role of agents of internalization (for example, in identifying the best motive for internalization, or in differentiating between sustainability or short-term economic interests), furthering interaction with world heritage mechanism (for instance, nominating other national parks into World Heritage List to pave the way for international monitoring, or encouraging interaction of more non-state actors), or furthering legal internalization (assessment on domestic laws to give effect to the Convention).

\section{References}

\section{Books}

Badan Nasional Penanggulangan Bencana, Data Bencana Indonesia 2017, Pusat Data, Informasi dan Humas, Jakarta, 2018.

Beham, Markus P., State Interest and the Source of International Law, Routledge, New York, 2018.

Cassese, Antonio, International Law, Oxford University Press, Oxford, 2001.

I.G.N. Anom, The Restoration of Borobudur, UNESCO, Paris, 2005.

Kementerian Lingkungan Hidup dan Kehutanan, Status Hutan dan Kehutanan Indonesia 2018, Kementerian Lingkungan Hidup dan Kehutanan, Jakarta, 2018.

Klabbers, Jan, The Concept of Treaty in International Law, Kluwer Law International, The Hague, 1996.

Osipova, Elena (et. al), The Benefit of Natural World Heritage: Identifying and Assessing Ecosystem Services and Benefits Provided by The World's Most Iconic Natural Places, IUCN, Gland, Switzerland, 2014.

Osipova, Elena (et. al), IUCN World Heritage Outlook 2: A Conservation Assessment of All Natural World Heritage Sites, IUCN, Gland, Switzerland, 2017.

Reis, Filipe dos and Oliver Kessler, "Constructivism and the Politics of International Law" in The Oxford Handbook of the Theory of International Law compiled by Anne Orford and Florian Hoffmann (et.al), Oxford University Press, Oxford, 2016.

Roskin, Michael G., "National Interest: From Abstraction to Strategy", in US Army War College Guide to Strategy compiled by Joseph R. Cerami and James F. Holcomb (et.al), US Army War College, Carlisle, Pennsylvania, 2001. 
United Nations, Asia Pacific Disaster Report 2019, UNESCAP, Bangkok, 2019.

UNESCO (et. al), Preparing World Heritage Nominations, UNESCO, Paris, 2011.

UNESCO (et. al), Managing Cultural World Heritage, UNESCO, Paris, 2013.

UNESCO (et. al), Managing Natural World Heritage, UNESCO, Paris, 2013.

UNESCO, World Heritage - Challenges for the Millennium, UNESCO, Paris, 2018.

Walhi, Tinjauan Lingkungan Hidup 2019, Wahana Lingkungan Hidup Indonesia, Jakarta, 2019.

\section{Other Documents}

Antaranews, "Pemerintah siapkan perlindungan efektif jaga warisan tambang Ombilin", https://www.antaranews.com/berita/945031/pemerintah-siapkanperlindungan-efektif-jaga-warisan-tambang-ombilin, accessed on August 7, 2019.

Antaranews, "Berstatus warisan dunia, WALHI minta stop aktivitas pertambangan", https://www.antaranews.com/berita/944845/berstatus-warisan-dunia-walhiminta-stop-aktivitas-pertambangan, accessed on August 7, 2019.

Badan Nasional Penanggulangan Bencana, Data Informasi Bencana Indonesia, http://bnpb.cloud/dibi/tabel1a, accessed on August 15, 2019.

Bambang Sulistyanto, Warisan Dunia Situs Sangiran: Persepsi Menurut Penduduk Sangiran", Wacana, Volume 11, No. 1, 2009.

Battini, Stefano, "The Procedural Site of Legal Globalization: The Case of the World Heritage Convention", International Journal of Constitutional Law, Vol. 9, No. 2, 2011.

Beritasatu, "Kunjungi Taman Nasional Komodo, Jokowi: Jaga dan Rawat", https://www.beritasatu.com/nasional/335865/kunjungi-taman-nasionalkomodo-jokowi-jaga-dan-rawat, accessed on August 9, 2019.

Berita Raya, "Kemenko PMK Minta Masyarakat Sadar Pentingnya Warisan Dunia, Ini Penjelasannya", https://www.beritarayaonline.co.id/kemenko-pmk-mintamasyarakat-sadar-pentingnya-warisan-dunia-ini-penjelasannya/, accessed on October 1, 2019.

Bisnis, "Peta Jalan SDGs Ditargetkan Selesai Tahun Ini", https://ekonomi.bisnis.com/190121/9/880734/peta-jalan-sdgs-ditargetkanselesai-tahun-ini, accessed on October 3, 2019.

Brumann, Christoph, "Shifting tides of world making in the UNESCO World Heritage Convention: cosmopolitanism colliding", Ethnic and Racial Studies, Vol. 37, No. 12, 2014.

Cakra Dunia, "Wagub: Geothermal di Gayo Lues Dibatalkan", http://cakradunia.co/news/wagub-geothermal-di-gayo-luesdibatalkan/index.html, accessed on September 22, 2019.

Capello, H.H. Krill de, "The Creation of United Nations Scientific, Educational, and Cultural Organization", Journal International Organization, Vol. 24, No. 1, 1970. 
Chechi, Alessandro, "Non-state Actors and the Implementation of the World Heritage Convention in Asia: achievements, problems, and prospects", Asian Journal of International Law, Vol. 8, No. 2, 2018.

CIFOR, "Laporan Tahunan 1998", https://www.cifor.org/publications/Html/AR98/Bahasa/W-Heritage.html, accessed on October 4, 2019.

CNN Indonesia, "BPJS kesehatan bisa deficit Rp 32,8T jika iuran tak naik", https://www.cnnindonesia.com/ekonomi/190827205233-78-425181/bpjskesehatan-bisa-defisit-rp328-t-jika-iuran-tak-naik__accessed on September 27, 2019.

Cole, Wade, "Mind the Gap: State Capacity and the Implementation of Human Rights Treaties", International Organization, Vol. 69, No. 2, 2015.

Conradin, Katharina and Urs Wiesmann, "Does World Natural Heritage Status Trigger Sustainable Regional Development Efforts?" Journal on Protected Mountain Areas Research and Management, Vol. 6, No. 2, 2014.

Conradin, Katharina and Thomas Hammer, "Making the Most of World Natural Heritage - Linking Conservation and Sustainable Regional Development?" Sustainability, Vol. 8, No. 4, 2016.

Detiknews, "Sawahlunto Jadi Warisan Dunia, Kemendikbud: Ini Kebanggaan Indonesia", https://news.detik.com/berita/d-4614279/sawahlunto-jadi-warisandunia-kemendikbud-ini-kebanggaan-indonesia, accessed on August 8, 2019;

Ellison, David, (et.al), "Trees, forests, and water: Cool insights for a hot world", Global Environmental Change, Volume 43, 2017.

Gatra, "Sumbar Komitmen Keluarkan Taman Kerinci Dari Status Bahaya", https://www.gatra.com/detail/news/439350/lifestyle/sumbar-komitmenkeluarkan-taman-kerinci-dari-status-bahaya, accessed on September 22, 2019.

Guzman, Andrew, "The Consent Problem in International Law", Berkeley Program in Law and Economics Working Paper Series, Berkeley, 2011.

IUCN, Mission Report - Tropical Rainforest Heritage of Sumatera, 5-11 March 2007, World Heritage Committee document 31 COM, 2007.

IUCN, Mission Report - Aeolian Islands, 21-28 March 2007, World Heritage Committee document 31 COM, 2007.

IUCN, Mission Report - Lorentz National Park, 24 January - 3 February 2011, World Heritage Committee Document 35 COM, 2011.

IUCN, Report on the Mission to Jakarta, from 24 to 30 October 2013, Regarding the Tropical Rainforest Heritage of Sumatera, IUCN, Gland, Switzerland, 2013.

IUCN, Mission Report - Lorentz National Park, 11-18 March 2014, World Heritage Committee Document 38 COM, 2014.

IUCN, Mission Report - Tropical Rainforest Heritage of Sumatera, 5-16 April 2018, World Heritage Committee Document 42 COM, 2018.

Kantor Staf Presiden, "Citra Positif Bukan Hanya Logo dan Slogan", http://ksp.go.id/presiden-jokowi-citra-positif-bukan-hanya-sekedar-logo-danslogan/index.html, accessed on August 112019. 
Katadata, "Menpar: Status internasional Ombilin Sawahlunto bakal tarik wisatawan", $\quad$ https://katadata.co.id/berita/19/07/09/menpar-statusinternasional-ombilin-sawahlunto-bakal-tarik-wisatawan, accessed on August 7, 2019.

Koh, Harold, "Transnational Legal Process", Nebraska Law Review, Vol. 75, No. 1, 1996.

Koh, Harold, "Why Do Nations Obey International Law", Yale Law Journal, Vol. 106, No. 4, 1997.

Koh, Harold, "Transnational Legal Process after September $11^{\text {th" }}$, Berkeley Journal of International Law, Vol. 22, No. 337, 1994.

Koh, Harold, "Bringing International Law Home", Houston Law Review, Vol. 35, 1998.

Meskell, Lynn, “UNESCO's World Heritage Convention at 40: Challenging the economic and political order of international heritage conservation", Current Anthropology, Vol. 54, No. 2, 2013.

Mongabay, "Situs Warisan Dunia Diupayakan Keluar Dari Status Bahaya, Begini Komitmen Pemerintah", https://www.mongabay.co.id/17/08/03/situs-warisandunia-diupayakan-keluar-dari-status-bahaya-begini-komitmen-pemerintah/_ accessed on September 22, 2019.

Ni Luh Herawati, “Pengembangan Pariwisata Berkelanjutan Berbasis Subak Sebagai Bagian Warisan Budaya Dunia UNESCO di Desa Mengesta Kabupaten Tabanan", Jurnal Master Pariwisata, Vol. 2, No. 1, 2015.

Pearce, Fred, "Rivers in the sky: how deforestation is affecting global water cycles", https://e360.yale.edu/features/how-deforestation-affecting-global-watercycles-climate-change, accessed on September 18, 2019.

Republika, "BNPB catat kerugian akibat kebakaran hutan 2015 Rp 221 triliun", https://nasional.republika.co.id/berita/nasional/umum/15/12/nzms82359-

bnpb-catat-kerugian-akibat-kebakaran-hutan-2015-rp-221-triliun_accessed on October 2, 2015.

Republika, "Presiden Jokowi Soroti Anggaran Riset Rp 24,9 Triliun: Itu Gede Banget", https://nasional.republika.co.id/berita/nasional/umum/15/12 //nzms82359-bnpb-catat-kerugian-akibat-kebakaran-hutan-2015-rp-221-triliun, accessed on October 2, 2018.

Semangatnews, "Gubernur Sumbar: Perlu Komitmen Menjaga Kawasan Warisan Alam Untuk Jaga Kepercayaan UNESCO", https://www.semangatnews.com/gubernur-sumbar-perlu-komitmen-menjagakawasan-warisan-alam-untuk-jaga-kepercayaan-unesco/?page28332434234=5, accessed on August 21, 2019.

Stevens, Caleb J., "Hunting a Dictator as a Transnational Legal Process: The Internalization Problem and the Hissene Habre Case", Pace International Law Review, Vol. 24, No. 1, 2012. 
Universitas Gadjah Mada, "80 persen bencana di Indonesia akibat perubahan iklim", https://ugm.ac.id/id/berita/8496-80-persen-bencana-di-indonesiaakibat-perubahan-iklim, accessed on August 15, 2019

Vrabel, JoAnn, "Tourism at UNESCO World Heritage Sites: Protecting Global Treasures and the Travelers Who Seek Them", Case Western Reserve Journal of International Law, Vol. 46, No. 3, 2014.

Wahana Lingkungan Hidup Indonesia, Siaran Pers tanggal 24 Oktober 2019, "Dalam Pusaran Oligarki, Masa Depan Suram Membayangi Pemerintahan Indonesia Maju", $\quad$ https://walhi.or.id/dalam-pusaran-oligarki-masa-depan-surammembayangi-pemerintahan-indonesia-maju, accessed on December 2, 2019

\section{Legal Documents}

Law Number 5 of 1990 on Conservation of Biodiversity and Ecosystem

Law Number37 of 1999 on Foreign Relations

Law Number 41 of 1999 and 19 of 2004 on Forestry

Law Number 4 of 2000 on Treaty

Law Number 17 of 2007 on Long-term National Development Plan

Law Number 26 of 2007 on Spatial Planning

Law Number 18 of 2013 on Prevention of Forest Degradation

The 2030 Agenda for Sustainable Development

Paris Agreement

Sendai Framework for Disaster Risk Reduction

The World Heritage Convention and its Operational Guidelines

The Vienna Convention on the Law of Treaties 